\title{
Discovery of Dreissena rostriformis bugensis (Andrusov 1897) in Western Europe
}

\author{
Daniel P. Molloy • Abraham bij de Vaate • \\ Thomas Wilke · Laure Giamberini
}

Received: 27 October 2006/ Accepted: 10 November 2006/Published online: 8 February 2007

(C) Springer Science+Business Media B.V. 2006

\begin{abstract}
Live individuals of Dreissena rostriformis bugensis were found in a trawlnet sample taken in April 2006 near Willemstad in the Hollands Diep, part of the main distributary in the Rhine delta in The Netherlands. This represented the first record of this species in Western Europe and a major westward range extension for this Ponto-Caspian species. Density was very low, with the ratio of Dreissena polymorpha to $D$. rostriformis bugensis in the order of 100:1. Mean length $(n=5) \quad$ was $22.5 \mathrm{~mm} \quad$ (range 20.4$24.6 \mathrm{~mm}$ ), suggesting that they were at least two years old and that the original introduction into the Hollands Diep had occurred in 2004 or earlier. Species identity was confirmed by mor-
\end{abstract}

D. P. Molloy ( $\square)$

Division of Research and Collections, New York State Museum, Albany, NY 12230, USA

e-mail: dmolloy@mail.nysed.gov

A. bij de Vaate

Waterfauna Hydrobiologisch Adviesbureau, Oostrandpark 30, NL-8212 AP, Lelystad, The Netherlands

T. Wilke

Department of Animal Ecology and Systematics, Justus Liebig University, D-35392 Giessen, Germany

\section{Giamberini}

Laboratoire Ecotoxicité et Santé Environnementale, UMR CNRS 7146, Université Paul Verlaine, 57070

Metz, France phological and molecular methods. We speculate that the invasion occurred through the MainDanube Canal - a pathway that is becoming increasingly recognized as a southern corridor for the potential movement of non-indigenous aquatic species between Eastern and Western Europe.

Keywords Introduced species - zebra mussels · Dreissena · Main-Danube Canal · Hollands Diep

\section{Introduction}

The Ponto-Caspian freshwater bivalve Dreissena polymorpha (Pallas 1771) quickly spread from Eastern to Western Europe during the 19th century through a corridor of river basins interconnected by man-made canals (Kinzelbach 1992). Over the last two centuries, this dreissenid species has continued its expansion into inland waters throughout much of Western Europe.

In contrast, another Ponto-Caspian species, Dreissena rostriformis bugensis (Andrusov 1897), has been far slower in its range expansion. Native to the Dnieper and Bug rivers and limans of the northern Black Sea, its distribution was limited to the Ukraine until about the middle of the 20th century (Therriault et al. 2005). Since then, an eastward expansion has occurred into Russia (Orlova et al. 2004; Zhulidov et al. 2004, 2005). Recently there have also been two reports 
of D. rostriformis bugensis in the Danube River within Romania, i.e., west of its native range. Micu and Telembici (2004) indicated finding $D$. rostriformis bugensis at Cernavoda $\left(44^{\circ} 21^{\prime} \mathrm{N}\right.$, $28^{\circ} 02^{\prime} \mathrm{E}$ ) in 2004 (\#1 in Fig. 1), and Popa and Popa (2006) observed this species the next year further westward ( $>500 \mathrm{~km}$ upriver) at Drobeta Turnu Severin (443' $13.68^{\prime \prime}$ N, 22 $40^{\circ} 49.40^{\prime \prime}$ E) (\#2 in Fig. 1). Noting these two recent Danube records, Mienis (2006) predicted that D. rostriformis bugensis would soon arrive in the Rhine River since these two rivers were now reconnected by the Main-Danube Canal. Since its reopening in 1992, this canal has been recognized as a potential new southern corridor for movement of non-indigenous aquatic species between Western and Eastern Europe (Bij de Vaate et al. 2002, Müller et al. 2002). Herein we provide evidence from The Netherlands that $D$. rostriformis bugensis is present in Western Europe and that its introduction likely occurred in 2004 or earlier.

\section{Discovery and Species Identification}

As part of a field project intended to document zebra mussel endosymbionts (Molloy and Giamberini, unpublished data), several thousand Dreissena were collected on April 19, 2006 with a trawlnet at a depth of 5-7 $\mathrm{m}$ in the Hollands Diep $\left(51^{\circ} 42^{\prime} 11^{\prime \prime} \mathrm{N}, 04^{\circ} 28^{\prime} 34^{\prime \prime} \mathrm{E}\right)$, part of the main distributary in the Rhine delta in The Netherlands (\#3 in Fig. 1). The zebra mussels collected were mainly attached to unionid shells (empty shells and live specimens). Since $D$. polymorpha was the only Dreissena sp. previously recorded from Western Europe, it was surprising to see that about $1 \%$ of the Dreissena completely lacked the distinctive ventro-lateral carina typical of D. polymorpha (Pathy and Mackie 1993). These latter specimens were subsequently identified as D. rostriformis bugensis since they morphologically possessed the key external and internal shell characteristics of this species (see description of the "quagga mussel" in Pathy and

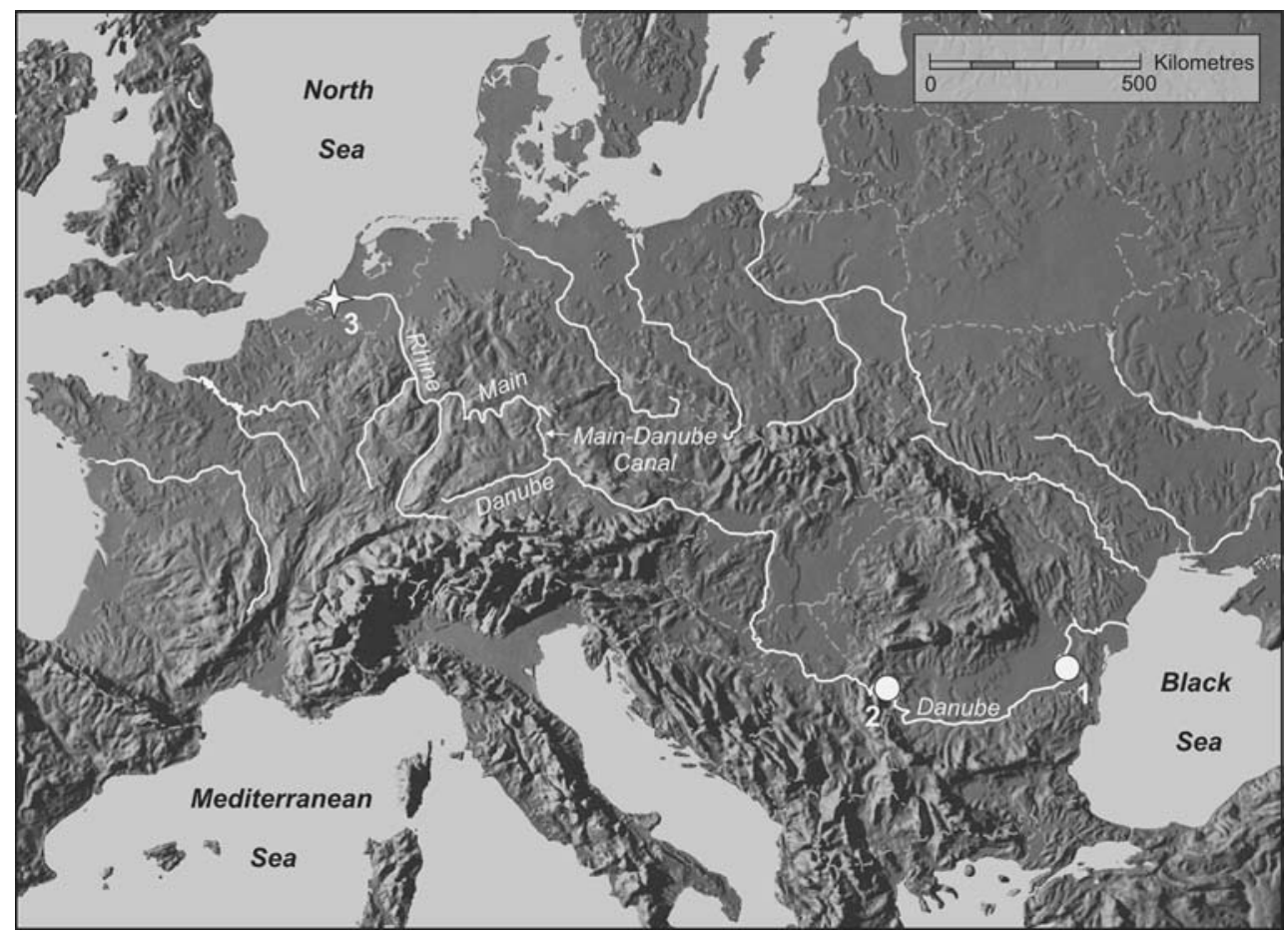

Fig. 1 Locations west of its native range where $D$. rostriformis bugensis has been field collected. (1) Danube River, Cernavoda, Romania in 2004 (Micu and Telembici 2004). (2) Danube River, Drobeta Turnu Severin, Roma- nia in 2005 (Popa and Popa 2006). (3) Hollands Diep, Willemstad, The Netherlands (present study). Map adapted from Mountain High Maps ${ }^{\circledR}$ Copyright $^{\circledR} 1993$ Digital Wisdom ${ }^{\circledR}$, Inc. 
Mackie 1993). Five of these D. rostriformis bugensis were randomly chosen and deposited as voucher specimens (\#159740) at the malacological department of the Zoological Museum Amsterdam. Their mean length (range) was 22.5 (20.4-24.6) $\mathrm{mm}$, suggesting that they were at least two years old and that the original introduction into the Hollands Diep had occurred in 2004 or earlier (Jantz and Neumann 1992, Smit et al. 1992).

To confirm the species identification using genetic markers, tissue samples from two of the above voucher specimens were fixed in $96 \%$ ethanol. DNA from each mussel was isolated using the CTAB protocol of Wilke et al. (2006). For amplification, we utilized the variable mitochondrial gene for cytochrome oxidase $c$ subunit I (COI), which is the most widely used marker for testing species level relationships in molluscs. The primers for amplifying a fragment of the COI gene were LCO1490 and HCO2198 as described by Folmer et al. (1994). Sequences (forward and reverse) of the two specimens were determined using the LI-COR (Lincoln, NE) DNA sequencer Long ReadIR 4200 and the Thermo Sequenase Fluorescent Labeled Primer Cycle Sequencing kit (Amersham Pharmacia Biotech, Piscataway, NJ). The DNA work yielded two identical, 638 base pair long fragments (GenBank accession numbers EF080861 and EF080862), one of which was used for BLAST searches in NCBI GenBank. The search returned, among others, three completely identical sequences of the COI gene, all belonging to D. rostriformis bugensis, i.e., GenBank accession number AF510504 of Therriault et al. (2004), DQ840132 of Gelembiuk et al. (2006), and DBU47651 of Baldwin et al. (1996).

There is an extreme degree of homogeneity in the mitochondrial COI genes of D. rostriformis bugensis. Although we suspect that the source of the introduction was the Main-Danube Canal, it was beyond the scope of this investigation to conduct additional molecular research involving highly variable markers needed to test this invasion route hypothesis. Additional sampling is now required in the Danube-Main-Rhine waterway between Romania and The Netherlands to ascertain if D. rostriformis bugensis has invaded the entire corridor or simply been vectored long-distance from the Romanian section of the Danube to The Netherlands' Rhine delta.

Dreissena polymorpha was first recorded in The Netherlands in 1827 (Van Benthem Jutting 1954). Thus, it has taken almost two centuries for D. rostriformis bugensis to catch up to the Western European populations of its Ponto-Caspian congeneric, D. polymorpha. Now that it has, will there be ecological consequences? Displacement of $D$. polymorpha populations by $D$. rostriformis bugensis has been commonly observed both in North American (Ricciardi and Whoriskey 2004) and in Eastern European (Orlova et al. 2004) waterbodies. The very low percentage of the Dreissena population represented by $D$. rostriformis bugensis at Hollands Diep suggests that if a similar pattern of displacement is occurring, it is only in its early stage.

Acknowledgements This research was funded in part by a travel grant from the Université Paul Verlaine-Metz to D.P.M.

\section{References}

Baldwin BS, Black M, Sanjur O, Gustafson R, Lutz RA, Vrijenhoek RC (1996) A diagnostic molecular marker for zebra mussels (Dreissena polymorpha) and potentially co-occurring bivalves: mitochondrial COI. Mol Mar Biol Biotechnol 5:9-14

Bij de Vaate A, Jazdzewski K, Ketelaars HAM, Gollasch S, Van der Velde G (2002) Geographical patterns in range extension of Ponto-Caspian macroinvertebrate species in Europe. Can J Fish Aquat Sci 59:11591174

Folmer O, Black M, Hoeh W, Lutz R, Vrijenhoek R (1994) DNA primers for amplification of mitochondrial cytochrome $c$ oxidase subunit I from diverse metazoan invertebrates. Mol Mar Biol Biotechnol 3:294-299

Gelembiuk GW, May GE, Lee CE (2006) Phylogeography and systematics of zebra mussels and related species. Mol Ecol 15:1033-1050

Jantz B, Neumann D (1992) Shell growth and aspects of the population dynamics of Dreissena polymorpha in the River Rhine. In: Neumann D, Jenner HA (eds) The Zebra Mussel Dreissena polymorpha: Ecology, Biological Monitoring and First Applications in the Water Quality Management, Gustav Fischer, New York, USA, pp 49-66

Kinzelbach R (1992) The main features of the phylogeny and dispersal of the zebra mussel Dreissena polymorpha. In: Neumann D, Jenner HA (eds) The Zebra Mussel Dreissena polymorpha: Ecology, Biological 
Monitoring and First Applications in the Water Quality Management, Gustav Fischer, New York, USA, pp 5-17

Micu D and Telembici A (2004) First record of Dreissena bugensis (Andrusov 1897) from the Romanian stretch of River Danube. In: Abstracts of the International Symposium of Malacology, August 19-22, 2004, Sibiu, Romania

Mienis HK (2006) Wanneer kunnen we Dreissena bugensis in de Rijn verwachten? (When may we expect Dreissena bugensis in the Rhine?) Spirula J Dutch Malacol Soc 350:70 (In Dutch with English summary.)

Müller JC, Hidde D, Seitz A (2002) Canal construction destroys the barrier between major European invasion lineages of the zebra mussel. Proc R Soc Lond B Biol Sci 269:1139-1142

Orlova MI, Muirhead JR, Antonov PI, Shcherbina GK, Starobogatov YI, Biochino GI, Therriault TW, MacIsaac HJ (2004) Range expansion of quagga mussels Dreissena rostriformis bugensis in the Volga River and Caspian Sea basin. Aquat Ecol 38:561-573

Pathy DA, Mackie GL (1993) Comparative shell morphology of Dreissena polymorpha, Mytilopsis leucophaeata, and the "quagga" mussel (Bivalvia: Dreissenidae) in North America. Can J Zool 71:10121023

Popa OP, Popa LO (2006) The most westward European occurrence point for Dreissena bugensis (Andrusov 1897). Malacol Bohemosl 5:3-5

Ricciardi A, Whoriskey FG (2004) Exotic species replacement: Shifting dominance of dreissenid mussels in the Soulanges Canal, upper St. Lawrence River, Canada. J North American Benthol Soc 23:507-514

Smit H, Bij de Vaate A, Fioole A (1992) Shell growth of the zebra mussel (Dreissena polymorpha (Pallas)) in relation to selected physico-chemical parameters in the Lower Rhine and some associated lakes. Arch für Hydrobiol 124:257-280

Therriault TW, Docker MF, Orlova MI, Heath DD, MacIsaac HJ (2004) Molecular resolution of the family Dreissenidae (Mollusca: Bivalvia) with emphasis on Ponto-Caspian species, including first report of Mytilopsis leucophaeata in the Black Sea basin. Mol Phylogenet Evol 30:479-489

Therriault TW, Orlova MI, Docker MF, MacIsaac HJ, Heath DD (2005) Invasion genetics of a freshwater mussel (Dreissena rostriformis bugensis) in eastern Europe: High gene flow and multiple introductions. Heredity 95:16-23

Van Benthem Jutting WSS (1954) Mollusca. In: De Beaufort LF (ed) Veranderingen in de Flora en Fauna der Zuiderzee (Thans IJsselmeer) na de Afsluiting in 1932 (Changes in the Flora and Fauna of the Zuyder Zee (at Present Lake IJsselmeer) after its Damming in 1932), Nederlandse Dierkundige Vereniging, De Boer, Den Helder, The Netherlands (In Dutch.), pp 233-252

Wilke T, Davis GM, Qiu D, Spear RC (2006) Extreme mitochondrial sequence diversity in the intermediate schistosomiasis host Oncomelania hupensis robertsoni: Another case of ancestral polymorphism? Malacologia 48:143-157

Zhulidov AV, Pavlov DF, Nalepa TF, Scherbina GH, Zhulidov DA, Gurtovaya TY (2004) Relative distributions of Dreissena bugensis and Dreissena polymorpha in the lower Don River System, Russia. Int Rev Hydrobiol 89:326-333

Zhulidov AV, Zhulidov DA, Pavlov DF, Nalepa TF, Gurtovaya TY (2005) Expansion of the invasive bivalve mollusk Dreissena bugensis (quagga mussel) in the Don and Volga River Basins: Revisions based on archived specimens. Ecohydrol Hydrobiol 5:127-133 